\title{
CZECH HOUSEHOLD TAX BURDEN ESTIMATION
}

\author{
Lukáš Moravec ${ }^{1}$, Gabriela Kukalová ${ }^{1}$ Jakub Ječmínek ${ }^{1}$, Luboš Žáček ${ }^{1}$

\begin{abstract}
${ }^{1}$ Department of Trade and Finance, Faculty of Economics and Management, Czech University of Life Sciences
\end{abstract} \\ Prague, Kamýcká 129, 16521 Prague, Czech Republic
}

To cite this article: MORAVEC LUKÁŠ, KUKALOVÁ GABRIELA, JEČMÍNEK JAKUB, ŽÁČEK LUBOŠ. 2018. Czech Household Tax Burden Estimation. Acta Universitatis Agriculturae et Silviculturae Mendelianae Brunensis, 66(6): 1557-1564.

To link to this article: https://doi.org/10.11118/actaun201866061557

\begin{abstract}
This paper solves the question of the Czech households' tax burden and its trend during the period from 2005 to 2015. Authors identified three groups of model Czech households based on the Czech Statistical Office data. The consumer basket structures, the median income, direct and indirect taxes rates were the parameters covered by the analyses. The weighted VAT tax rates were calculated for the consumer basket items valid for the year 2015. The year 2015 was used as the reference one for the rest of the period. The results show the estimated cumulative tax burden including direct and indirect taxation in 2015 and the previous years. The paper identified the changes and the trend of taxation level relating the Czech households.
\end{abstract}

Keywords: consumer basket, tax mix, tax burden, household, direct taxes, indirect taxes

\section{INTRODUCTION}

The tax burden is usually defined as the total amount of tax as a proportion of GDP. The amount of the tax burden is expressed in the tax quota. The OECD survey (OECD, 2016) results show that the tax burden in OECD countries continued. The data also show that the tax structure is shifting towards labor taxation and consumption taxes. The Czech Republic ranked with its tax burden of 33.5\% of GDP in 2015 among the bellow-average countries. The structure of its tax revenues is different from most OECD countries, $44 \%$ of income is from social insurance contributions (OECD average is of $26 \%$ ). For the OECD countries, an alternative tax burden approximation called the Adjusted Tax Quota (Kotlan et al., 2015) is created. The interaction between tax and economic growth in OECD countries describes an analysis aimed at verifying the negative impact of the effective tax burden on economic growth.
The results show that taxes have an adverse impact on economic growth (Kotlan and Mach, 2013). However, the tax burden may have other impacts, as shows for example the hypothesis tested in 1959-2006, which focused on the impact of the tax burden on the US president's assessment. The result of the study is that there is a negative impact of the size of the tax burden, the deficit and changes in the tax structure on the presidential rating (Geys and Vermeir, 2008). In 2012, a study on tax burden measurement options was produced, the results of this study show that the less appropriate indicator is the statutory tax rate followed by the tax quota. The most appropriate indicator of tax burden according to this study is the World Tax Index, which is based on a combination of soft and hard data (Baranová, 2012).

There are many tax-burden surveys that determine or compare the tax burden. A comparison of the effective tax rate for the 15 EU Member States presents a study (Bustos-Contell et al., 2017) which 
examined changes in effective tax rates between 2006 and 2014. The creation of the single market is one of the priorities of the EU integration process. It is also planned to unify tax rules across the Community (Bušovská, 2014). Annual EU countries data from 2003 to 2012 were used for a study showing that there are large differences in tax burden in the EU. The tax burden on capital and consumption is higher in countries with higher economic development. The accession to the EU in 2004 or 2007 had a major impact on the change in tax burden in these countries (Sineviciene, 2016). The acceding countries in 2004 or 2007 are in a group of countries with a low tax burden and their effort was to motivate future investors with favourable tax rates (Šimková, 2015). According to Teplická and Daubner (2013), the tax competition is linked to lower government spending in public services; it leads to higher economic growth, increases tax burden on consumption, and the budget deficit acts as a negative factor in tax competition. Nadoveza et al. (2016) states that in Croatia it is possible to support domestic production by reducing the income tax on natural persons. Member States increased several times the VAT rate in between 2007-2013, which should lead to an effort to consolidate public budgets. The Czech Republic has changed the VAT rate several times (Široký and Stř́lková, 2014). These changes have an impact on household spending as well as the transfer of commodities between reduced and standard VAT rates (Stř́lková and Široký, 2015).

Based on the results of a study by Mazanec and Bieliková (2017), that analyzed and compared the tax burden on wages in the Czech and Slovak Republics, it can be said that the higher tax burden is in the Slovak Republic. In both countries there are many differences that have a direct effect on the calculation of the net income of the employee (Pšenková, 2016). In recent years, the Slovak Republic has tended to have stricter rules on the application of tax deductible costs in order to achieve the highest possible tax collection on the basis of tax legislation. This assertion supports the amendment to the Income Tax Act as of January 1, 2015 (Vašeková and Mateášová, 2017). Based on an analysis that collected data from 2006-2011, the difference in taxation of employees and self-employed in the Czech Republic still exists and has increased in recent years (Finardi and Vančurová, 2014). The Czech Republic is one of the countries with a low-efficiency and not very flexible labour market. The tax burden is high and is due to the amount of social and health insurance.
(Janoušková, 2011). The size of the tax burden in the Czech Republic affects the workforce and revenues to the state budget. The comparison of the tax burden on legal entities and employees shows a gradual decrease in the tax burden along with the increasing inequality of its distribution in different forms of work. The highest decrease was recorded in the tax burden on legal entities. This analysis shows that the size of the contribution to social and health insurance is the most important tax burden factor (Kovárník and Jedlička, 2017).

The studies mentioned above are focused on the total tax burden, tax quotes or the studies are aimed at one concrete tax or group of taxes as income taxes or excise taxes. Probably the most frequent topic is the labour tax burden and corporate income tax burden and profit shifting recently. The issue of total household's tax burden complex study is rare or avoided in the published articles.

Due to the lack of studies our research focused on the all relevant taxes influencing the households tax burden in the Czech Republic to bring as complex view as possible. The research originality consists in the complexity of the study. Moreover, the outputs bring interesting new contribution to the current state of art as the research tests tax burden disproportion among tree model groups of households based not only on labour taxation but also on different structures of their consumption baskets.

\section{MATERIALS AND METHODS}

Calculations of the tax burden will be applied to three model household groups. From the statistical information on the structure of households, it is possible to determine which groups of households are most represented in the Czech Republic. The first group of households to which the tax burden is calculated is the household of a complete family of a married couple. Both members of the household are in employment. The second group of households is the household of a married couple with dependent children. The average number of children per family is 1.6. For the completeness of the calculation, this number is rounded, and the second group is made up of two adults in employment and two dependent children. The last represented group of households in this research is the single-person household of an individual who is in an employment relationship.

\section{Tax burden on households by direct taxes}

Taxes and contributions, which are repeated on a regular basis, were selected for the analysis

I: Households'models specification

\begin{tabular}{ccc}
\hline Household & Number of members & Description \\
\hline $1^{\text {st }}$ group & 2 & Man and woman in marital relationship, childless. \\
$2^{\text {nd }}$ group & 4 & Man and woman in marital relationship, 2 dependent children. \\
$3^{\text {rd }}$ group & 1 & No gender is defined, based on median. \\
\hline
\end{tabular}

Source: CZSO (2015c), own work 
of the tax burden on households through direct taxes. These include income tax and social security contributions and health insurance payments. From direct taxation was also analyzed the tax burden based on real properties taxes. For research purposes the households covered by the models are expected to have income as employees. These revenues are relatively highly transparent and possible distortion of the results can be minimized. To determine the value that households transfer from their incomes to the state treasury, it is necessary first to determine their income. Household income was based on a median wage. In Q1 2015 the median wage was 21,143 CZK, for men it was 23,035 CZK, for women 18,998 CZK (CZSO, 2015b). From the selected household groups, their total gross income can be determined (Tab. II). From mentioned incomes was calculated the income tax and contributions to social security and health insurance (contributions of employee and employer's contributions payable for employees).

Population Census in 2011 shows that the largest number of people lives in a family home, with a population of $3,566,841$. The second most common dwellings are residential buildings. For research it will be determined that household number 1 is living in apartment $2+1$. Household number 2 occupies a family house and household number 3 resides in apartment $1+1$. To determine the tax, it is also necessary to specify the real estate area. The first household lives in an apartment with a total area of $50 \mathrm{~m}^{2}$. The second household lives on a plot of $500 \mathrm{~m}^{2}$ and a built-up area of $100 \mathrm{~m}^{2}$. The third single household lives in an apartment of $25 \mathrm{~m}^{2}$. Another criterion for tax calculation is the area in which the property is located. The Coefficients influencing the final tax real estate value are based on the number of inhabitants, nevertheless they can be easily changed annually by the municipal council, so the coefficients values might be changed significantly every year. The population statistics in the municipalities of the Czech Republic show that the most populous city is the capital city of Prague with 1,259,079 inhabitants, covering above $10 \%$ of population.
Therefore, the real estate tax burden model was built on the coefficients applied in the country 's capital in the relevant period in the study, which means also the upper limit of real estate tax in the Czech Republic is used. The municipality-by-population coefficient that multiplies the tax rate is 5, the local coefficient multiplying the calculated tax was set at 4. The model household groups' dwellings specification is shown in Tab. III.

\section{Tax burden on households of indirect taxes}

Indirect taxes having impact on household's burden include value added tax and consumption tax. To calculate the cost of individual taxes, it was necessary first to determine the expenditures of households, respectively, consumer household basket. In economic theory, the consumer basket represents the model consumption of the average household. It contains several hundred items, which are aggregated into 12 groups (e.g. clothing, food, transport, recreation, etc.), and the importance of individual items is determined by their representation in the average household expenditure. Thus, the consumer basket represents a representative group of goods.

Considering that in the Czech Republic is not determined consumer basket mapping household expenditures, for the research will be used the Consumer basket for the calculation of the consumer price index from January 2015. This consumer basket is compiled by the Czech Statistical Office in order to determine the inflation rate. There are 692 items of goods and services in the consumer basket. Each item has a weight in the index, depending on how it is involved in household consumption expenditure. The most important are housing, energy, water and fuel prices. On the second place are prices of food and non-alcoholic beverages and transport prices are third.

This consumer basket is used for calculating the burden on households by indirect taxes. Within these twelve groups, an average value of VAT can be determined for each group, which was determined from the average VAT rates of each item of

II: Median incomes of model groups of households

\begin{tabular}{ccc}
\hline Household & Gross monthly income (CZK) & Gross annual income (CZK) \\
\hline $1^{\text {st }}$ group & 42,033 & 504,396 \\
$2^{\text {nd }}$ group & 42,033 & 504,396 \\
$3^{\text {rd }}$ group & 21,143 & 253,716 \\
\hline
\end{tabular}

Source: CZSO (2015b), own work

III: Dwelling specification of household model groups

\begin{tabular}{ccccc}
\hline Household & Type of dwelling & Area & Coefficient & Local coefficient \\
\hline $1^{\text {st }}$ group & Apartment $2+1$ & $50 \mathrm{~m}^{2}$ & 5 & 4 \\
$2^{\text {nd }}$ group & Family house $3+1$ & $100 \mathrm{~m}^{2}$ & 5 & 4 \\
$3^{\text {rd }}$ group & Apartment $1+1$ & $25 \mathrm{~m}^{2}$ & 5 & 4 \\
\hline
\end{tabular}

Source: CZSO (2015c), own work 
the consumer basket. Since within the framework of one group only a number of items with individual tax rates would be averaged, the VAT rate was compared to the weight of its item and thus the weighted VAT rate was obtained. From the weighted VAT rate derives the exact proportion of the VAT value. This calculation can accurately reflect the ratio of VAT rates to the value of individual items (Tab. IV). For example, for Post and Telecommunications, the VAT rate is $21 \%$, some specific items in this group have the same VAT rate, others are VAT-exempt. E.g. item Mobile phone - the device and services have a VAT rate of $21 \%$; the other two items of the Postage are exempt from VAT. If the average of the rates was set, its value would be $10.5 \%$. However, this value does not reflect the importance and representation in household consumption. The item Phone and fax services have a weight of $28.32 \%$ (VAT $21 \%$ ), the item Mobile device $1.61 \%$ (VAT 21\%), and Postage Service (VAT-exempt) have a weight of $0.43 \%$ and $0.22 \%$. After taking into account the weight of the items, the weighted rate is $20.55 \%$, which reflects the true value of VAT.

In the tax burden of model groups of households, consumption taxes are also taken into consideration, which for some goods form a significant part of their price. Therefore, items that are included in the consumer basket have been analyzed. These are: alcoholic beverages, tobacco and fuel (Tab. IV).

\section{Tax burden of households between 2005 and 2015}

Another part of the research was aimed at the tax burden on model groups of households during a 10-year period (2005-2014) preceding the reference year 2015. For comparison of the tax burden in individual years, median income from Q1 2015 was set as the reference income of model households. At the same time, it was based on the consumer basket of the Czech Statistical Office (CZSO) (2015a). In the period 2005-2014, the tax burden on model groups of households by direct and indirect taxes were analyzed. As in the reference year 2015, for the analysis in the period 2005-2014 were used income tax on dependent activity, social security contributions and health insurance, real estate tax, VAT and consumption taxes.

All these mentioned taxes registered in analyzed period 2005-2015 changes in rates that influenced the partial and total tax burden on model groups of households. During the analyzes all relevant changes in concerned taxes rates and mandatory payments were taken into account. Income tax takes into consideration the method of setting the tax, changement of the rate, the amount of reliefs and the dependent child tax benefit. As concerns the social security insurance, the changes in contribution rates were included in the calculations (the rate for health insurance was not changed in the analyzed period). When analyzing the tax burden on real estate taxes, changes in rates and coefficients have been taken into consideration. Significant changes in rates in the analyzed period were included in the calculations of the VAT tax burden. At the beginning of the analyzed period (2005), the basic VAT rate was $19 \%$ and the reduced rate was $5 \%$, in 2015 the basic rate was $21 \%$, the first decreased rate was $15 \%$ and the second decreased rate was $10 \%$. Changes in consumption tax rates have also been taken into account, the most significant and regular increase in the tax rate was on tobacco products.

\section{RESULTS}

The results of analyzes of tax burden in the reference year 2015 on individual model groups of households show a high labour taxation (dependent activity) in the Czech Republic. At the same time in the analyzed period, there is evident a gradual reduction in the tax burden on personal income tax (with slight fluctuations in some years). In the case of other taxes, however, the increase of tax burden on the model groups of households is noticeable. Personal income tax on dependent

IV: Consumerbasket

\begin{tabular}{lcc}
\hline \multicolumn{1}{c}{ Type of goods and services } & Share in consumer basket (\%) & Weighted rate of VAT (\%) \\
\hline Food and non - alcoholic beverages & 17.03 & 15.00 \\
\hline Alcoholic beverages, tobacco & 8.59 & 21.00 \\
\hline Clothing and footwear & 4.72 & 21.00 \\
Housing, water, energy, fuel & 25.34 & 9.24 \\
Housing equipment, household equipment, repairs & 5.52 & 21.00 \\
Health & 2.50 & 8.50 \\
Transport & 11.49 & 20.55 \\
Post and Telecommunication & 3.99 & 20.55 \\
Recreation and culture & 9.37 & 18.32 \\
Education & 0.78 & 0.00 \\
Boarding and accommodation & 4.43 & 17.27 \\
\hline Other goods and services & 6.24 & 15.08 \\
\hline
\end{tabular}

Source: CZSO (2015a), own research 
activities and compulsory employee's social and health insurance contributions significantly reduce the employee's income. Even more significant is the burden of social security and health insurance payments of the employer, which is 34\% higher, added to the gross wage of an employee. The total tax burden on the income of the first and third groups of households is $37.7 \%$ (Tabs. VI and VII).

The evolution of net wages in the household model groups shows a gradual moderate reduction of the tax burden on wages, especially for the group of households with dependent children. The highest burden on households was spent in 2005, when the first household paid tax CZK 5,212 and the third household 2,622 CZK.
Even the second household with children had the highest burden in 2005, namely CZK 4,203. The lowest burden had childless households in 2010 with CZK 3,867 for the first group of households and CZK 1,945 for the third group of households. The second household has the lowest income tax from 2012 until the end of the analyzed period. Net wages of model household's groups were higher in 2015 than at the beginning of the analyzed period (Fig. 1). For households group 1 and 3, the net wage increased approximately by $4.8 \%$, the net wage difference compared to 2005 and 2015 is noticeable especially for the second group of households with dependent children, and the net wage increase of the household is $9 \%$.

V: Tax burden $2015-1^{\text {st }}$ group of households

\begin{tabular}{lccc}
\hline \multicolumn{1}{c}{ Tax/Insurance } & Monthly payment (CZK) & Annual payment (CZK) & Tax burden (\%) \\
\hline Income tax & 4,309 & 51,704 & 10.3 \\
\hline Social insurance & 2,732 & 32,786 & 6.5 \\
Health insurance & 1,891 & 22,698 & 4.5 \\
Real estate tax & 200 & 2,400 & 0.48 \\
VAT & 5,024 & 60,291 & 12.0 \\
Consumption taxes & 1,694 & 20,326 & 4.0 \\
Total & $\mathbf{1 5 , 8 5 0}$ & $\mathbf{1 9 0 , 2 0 5}$ & $\mathbf{3 7 . 7}$ \\
Social and health insurance - employer & 14,291 & 171,495 & 34.0 \\
Total, including employer's contribution & 30,141 & 361,700 & 53.5 \\
\hline So
\end{tabular}

Source: own research

VI: Tax burden 2015 - $2^{\text {nd }}$ group of households

\begin{tabular}{lccc}
\hline \multicolumn{1}{c}{ Tax/Insurance } & Monthly payment (CZK) & Annual payment (CZK) & Tax burden (\%) \\
\hline Income tax & 1,874 & 22,482 & 4.5 \\
Social insurance & 2,732 & 32,786 & 6.5 \\
Health insurance & 1,891 & 22,698 & 4.5 \\
Real estate tax & 458 & 5,500 & 1.09 \\
VAT & 5,394 & 64,724 & 12.8 \\
Consumption taxes & 1,818 & 21,816 & 4.3 \\
Total & 14,168 & 170,020 & 33.7 \\
Social and health insurance - employer & 14,291 & 171,495 & 34.0 \\
Total, including employer's contribution & 28,459 & 341,515 & 50.9 \\
\hline
\end{tabular}

Source: own research

VII: Tax burden 2015 - $3^{\text {rd }}$ group of households

\begin{tabular}{lccc}
\hline \multicolumn{1}{c}{ Tax/Insurance } & Monthly payment (CZK) & Annual payment (CZK) & Tax burden (\%) \\
\hline Income tax & 2,180 & 26,157 & 10.3 \\
Social insurance & 1,374 & 16,492 & 6.5 \\
Health insurance & 951 & 11,417 & 4.5 \\
Real estate tax & 100 & 1,200 & 0.47 \\
VAT & 2,525 & 30,304 & 11.9 \\
Consumption taxes & 851 & 10,217 & 4.0 \\
Total & 7,981 & 95,787 & 37.7 \\
Social and health insurance - employer & 7,189 & 86,263 & 34.0 \\
Total, including employer's contribution & 15,170 & 182,050 & 53.5 \\
\hline
\end{tabular}

Source: own research 


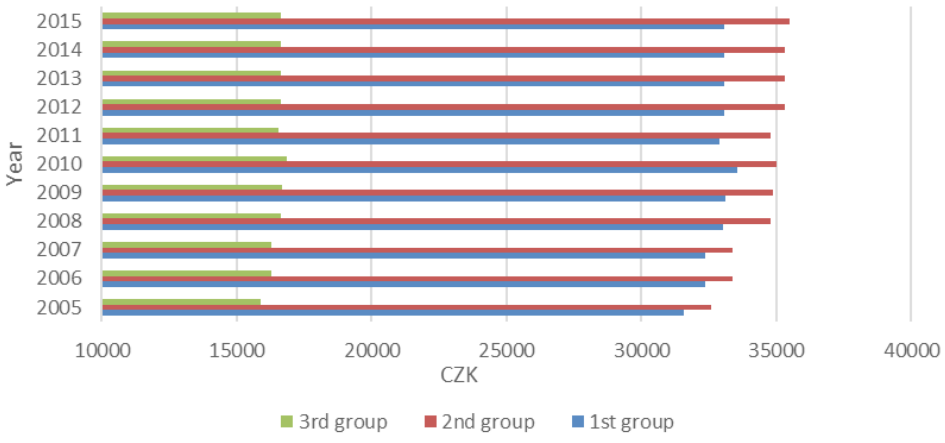

1: Net wage in model groups of households in the period 2005-2015

Source: The Czech Rep. (1992b, 1992c, 1992d), own research

The results of the overall tax burden on model groups of households in the period 2005-2015 show that the tax burden on income, compulsory social security and health insurance payments are the highest part of the total burden on household income (Tab. VIII). The income tax burden for the analyzed period 2005-2015 is almost constant for the lst and 3rd groups of households (except for 2005 and 2010). For the 2nd group of households, there is a noticeable reduction in the tax burden on income taxes, particularly as a result of the dependent child keeping tax bonification. The tax burden by other relevant taxes shows an increase in the reported period. Growth is particularly evident in value added tax.

\section{DISCUSSION}

The results of tax burden analyze of model groups of households show high taxation of labour in the Czech Republic, both on the side of the employee and particularly of the employer. These results correspond to OECD data (2016), according to which the burden of social and health insurance contributions in the Czech Republic is above average. Moreover, the amount of social and health insurance contributions is the most important factor of tax burden, according to Kovárník and Jedlička (2017).

An interesting result was the comparison of net wages. The largest increase in net wage was recorded for the 2nd group of households, by 9\% in 2015 compared to 2005 (for other households, net wage growth was $4.8 \%$ ). The decrease of the tax burden of the 2nd group of households in 2015 (especially compared to previous years 2012-2014) is due to an increase of the tax advantage for the second child. The tax burden analyzes that are the subject of another part of our research (which is currently taking place) show further reduction of income tax from dependent employment in households with dependent children as a result of the gradual increase of the dependent children tax benefits in 2016-2018.

As concerns other taxes, the results show a gradual increase in the tax burden of the model households. The tax burden on immovable property increased in 2009 and 2010. Local coefficients were introduced in 2009 and the tax rate increased in 2010, reflecting an increase in the tax burden on real estate taxes of more than $60 \%$ for all model households (when comparing 2005 and 2015).

VIII: Tax burden on model groups of households in the period 2005-2015

\begin{tabular}{|c|c|c|c|c|c|c|c|c|c|c|c|c|c|c|c|c|c|c|}
\hline & \multicolumn{3}{|c|}{ Income tax (\%) } & \multicolumn{3}{|c|}{$\begin{array}{l}\text { Social and health } \\
\text { insur. (\%) }\end{array}$} & \multicolumn{3}{|c|}{ Real Estate Tax (\%) } & \multicolumn{3}{|c|}{ VAT (\%) } & \multicolumn{3}{|c|}{$\begin{array}{c}\text { Consumption taxes } \\
(\%)\end{array}$} & \multicolumn{3}{|c|}{$\begin{array}{c}\text { Household total } \\
\text { (\%) }\end{array}$} \\
\hline & $1^{\text {st }} \mathrm{gl}$ & & $3^{\text {rd }} \mathrm{gr}$. & $1^{\text {st }}$ gr. & and on & $3^{\text {rd }} \mathrm{gr}$. & $1^{\text {st }} \mathrm{gr}$ & Ond & ordo & $1^{\text {st }} \mathrm{g}$ & $2^{\text {nd }}$ & $3^{\text {rd } g}$ & $1^{\text {st }} g$ & ond & $3^{\text {rd }} \mathrm{gr}$. & $\mathbf{1}^{\text {st }} \mathrm{gr}$ & 9nd & $3^{\text {rd }} \mathrm{gr}$ \\
\hline 005 & 124 & 10.0 & 12.4 & 12.5 & 125 & 125 & 0.29 & 0.67 & 0.29 & 9.7 & 10.4 & 9.7 & 32 & 3.5 & 3.2 & 38.1 & 37.1 & 38.1 \\
\hline 2006 & & & & & & & & & & 9 & & & & & & & & 36.3 \\
\hline 007 & & & & & & & & & & & & & & & & & & 36.4 \\
\hline 2008 & & & & & & & & & & & & & & & & & & \\
\hline 2009 & & & & & & & & & & & & & & & & & & 35.2 \\
\hline 2010 & & & & 1.0 & & 1.0 & 0.48 & & 0.47 & 10. & & 10.5 & & & & 35.1 & & 35.0 \\
\hline 2 & & & & & & & & & & & & & & & & & & 36.6 \\
\hline 2012 & & & & & & & & & & & & & & & & & & 37.3 \\
\hline & & & & & & & & & & & & & & & & & & 37.9 \\
\hline 2014 & & & & 1.0 & & & 0. & & & 12.3 & & 12. & 4. & & & 38.0 & & 38.0 \\
\hline 2015 & 10.3 & 4.5 & 10.3 & 11.0 & 11.0 & 11.0 & 0.48 & 1.09 & 0.47 & 12.0 & 12.8 & 11.9 & 4.0 & 4.3 & 4.0 & 37.7 & 33.7 & 37.7 \\
\hline
\end{tabular}

Source: CZSO, own research 


\section{CONCLUSION}

The tax burden increase is the cumulative effect of changes in the Czech tax system as consequences of the Czech state tax policy response and the municipal tax policy reaction at the same time to the crisis in 2008. The analysis of the tax burden on value added tax and consumption taxes show a noticeable shift of tax burden towards consumption. The value added tax burden was approximately by $23 \%$ higher in all model groups of households in 2015 than in 2005. Effects of changes in VAT rates on household expenditures are reported, for example, by Stř́lková and Široký (2015). Similar results were obtained for consumption taxes when comparing the years 2005 and 2015. For groups 1 and 3 the tax burden increased by $25 \%$, for the 2 nd group of households by $22.9 \%$. The OECD survey (2016) also highlights the shift towards consumption taxes in line of the current study results. The complex evaluation of household's tax burden in the Czech Republic or any state was not realized according to available sources. The known and published studies are aimed at differences in income taxation or total labour tax burden diversification (Jones and O'Hara, 2016; Nadoveza et al., 2016; Stoewhase, 2016). The presented research covers the unique complex evaluation of the different model households total tax burden.

\section{Acknowledgements}

This paper is a partial result of the research project No. 20171032-Czech tax gap as a consequence of profit shifting quantification and its factors identification, supported by the Internal Grant Agency (IGA) of Faculty of Economics and Management, CULS Prague.

\section{REFERENCES}

BARANOVÁ, V. 2012. Methods of Tax Burden Measurement: APractical Case for European Union Countries. In: Proceedings from the $2^{\text {nd }}$ International Scientific Conference Taxes in the World. Brno: European Association Comenius - EACO, pp. 7-26.

BUŠOVSKÁ, M. 2014. Convergence of Tax Burden, Tax Revenues and Implicit Tax Rates in the European Union Member States. Ekonomický časopis, 62(4): 363-376.

BUSTOS-CONTELL, E., CLIMENT-SERRANO, S. and LABATUT-SERER, G. 2017. Offshoring in the European Union: A Study of the Evolution of the Tax Burden. Contemporary Economics, 11(2): 235-247.

CZECH STATISTICAL OFFICE. 2015a. Consumer basket. Prague: Czech Statistical Office. [Online]. Available at: https://www.czso.cz/csu/czso/spotrebni_kos_archiv [Accessed: 2017, September 12].

CZECH STATISTICAL OFFICE. 2015b. Average wages: $1^{\text {st }}$ quarter. Prague: Czech Statistical Office. [Online]. Available at: https://www.czso.cz/csu/czso/cri/prumerne-mzdy-l-ctvrtleti-2015 [Accessed: 2017, September 12].

CZECH STATISTICAL OFFICE. 2015c. Population Censuses. Prague: Czech Statistical Office. [Online]. Available at: https://www.czso.cz/csu/czso/cri/prumerne-mzdy-l-ctvrtleti-2015 [Accessed: 16 September 2017]. In Czech.

FINARDI, S. and VANČUROVÁ, A. 2014. Tax Burden on Employment and Self-employment Activity in the Czech Republic. In: Proceedings of the $19^{\text {th }}$ International Conference: Theoretical and Practical Aspects of Public Finance. Praha: Wolters Kluwer Česká republika, pp. 46-52.

GEYS, B. and VERMEIR, J. 2008. Taxation and presidential approval: separate effects from tax burden and tax structure turbulence? Public Choice, 135(3-4): 301-317.

JANOUŠKOVÁ, J. 2011. Labour Cost and Tax Burden of the Firm. In: Proceedings of Hradec Economic Days 2011, Part I: Economic Development and Management of Regions. February 4th and 5th, 2014 Hradec Králové, Czech Republic. University of Hradec Králové, pp. 107-113.

JONES, M. R. and O'HARA, A. B. 2016. Do Doubled-up Families Minimize Household-level Tax Burden? National Tax Journal, 69(3): 613-640.

KOTLAN, I. and MACHOVÁ, Y. 2013 The Impact of the Tax Burden on the Living Standard in OECD Countries. Ekonomický časopis, 61(9): 951-962.

KOTLAN, I., MACHOVÁ, Z. and MACEK, R. 2015. Not a Tax as a Tax: Tax Burden Indicators Revised. In: Innovation Vision 2020: From Regional Development Sustainability to Global Economic Growth, Vol I-VI, pp. 981-991.

KOVÁRNÍK, J. and JEDLIČKA, P. 2017. The Analysis of Tax Burden on Labor in the Czech Republic. Country Experiences in Economic Development, Management and Entrepreneurship, 5: 281-292.

MAZANEC, J. and BIELIKOVÁ, A. 2017. The Comparison of Tax Burden of Employees in the Czech and Slovak Republic. In: $4^{\text {th }}$ International conference on economic, business management and education innovation (EBMEI 2017), 86: 27-36.

NADOVEZA, O., SEKUR, T. and BEG, M. 2016. General Equilibrium Effects of Lower Labor Tax Burden in Croatia. Zagreb International Review of Economics $\odot$ Business, 19: 1-13. 
OECD. 2016. Revenue Statistic: 1965-2016. OECD. [Online]. Available at: http://www.oecd.org/tax/revenuestatistics-2522770x.htm\#RS-COUNTRY-SUMMARIES. [Accessed: 2017, October 28].

PŠENKOVÁ, Y. 2016. Comparison of Tax Burden of Incomes from the Dependent Activity of Employees in the Czech Republic and Slovak Republic in the Context of Globalization Trends. In: Globalization and its Socio-Economic Consequences, 16th International Scientific Conference Proceedings, Pts I-V. 5-6t October 2016, Rajecke Teplice, Slovak Republic. Žilina: University of Žilina, pp. 1832-1839.

SINEVICIENE, L. 2016. Tax Burden and Economic Development: The Case of the European Union Countries. Entrepreneurship, Business and Economics, 2(3-2): 283-298.

STOEWHASE, S. 2016. Horizontal Inequities in the German Tax-Benefit-System: The Case of Two Wage-Earner Employee Households. Journal of Family and Economic Issues, 37(2): 313-329.

STŘÍLKOVÁ, R. and ŠIROKÝ, J. 2015. Changes in the VAT burden on expenses of selected households in the Czech Republic (2007-2013). In: 18 $8^{\text {th }}$ International Conference Enterprise and Competitive Environment. Brno: Mendeli University in Brno, pp. 842-851.

ŠIMKOVÁ, N. 2015. The Hierarchical Clustering of Tax Burden in the EU27. Journal of Competitiveness, 7(3): 95-109.

ŠIROKÝ, J. and STŘÍLKOVÁ, R. 2014. Changes in the VAT Burden on Expenses of a Selected Household in the Czech Republic (2007-2012). In: Proceedings of the 19 ${ }^{\text {th }}$ International Conference: Theoretical and Practical Aspects of Public Finance. Praha: Wolters Kluwer Česká republika, pp. 296-305.

TEPLICKÁ, K. and DAUBNER, M. 2013. Study of the Relation between Tax Competition and Tax Burden in European Union Member States. Ekonomický časopis, 61(2): 172-186.

VAŠEKOVÁ, J. and MATEÁŠOVÁ, M. 2017. Analysis of Tax Burden in the Slovak Republic with Emphasis on Depreciation. In: New trends in finance and accounting: Proceedings of the 17th Annual Conference on Finance and Accounting. Springer, pp. 271-279.

Contact information

Lukáš Moravec: moravec@pef.czu.cz

Gabriela Kukalová: kukalova@pef.czu.cz

Jakub Ječmínek: jecminek@pef.czu.cz

Luboš Žáček: zlubo@seznam.cz 